\title{
Estimates of the Potential Cost of Emerald Ash Borer (Agrilus planipennis Fairmaire) in Canadian Municipalities
}

\author{
Daniel W. McKenney, John H. Pedlar, Denys Yemshanov, D. Barry Lyons, Kathy L. Campbell, \\ and Kevin Lawrence
}

\begin{abstract}
Emerald ash borer (EAB) is an invasive phloem-feeding insect causing extensive mortality to ash (Fraxinus sp.) in North America. Economic costs associated with EAB-related mortality of street and backyard trees in Canadian urban areas were estimated over a 30-year time horizon. The approach employed a simple spread model to approximate EAB arrival times at each community based on three maximum spread rates: slow $(\sim 10 \mathrm{~km} / \mathrm{year})$, medium $(\sim 30 \mathrm{~km} / \mathrm{year})$, and fast $(\sim 50 \mathrm{~km} / \mathrm{year})$. Costs are estimated for four discount rates $(0 \%, 2 \%, 4 \%$, and $10 \%)$ and three treatment rates $(0 \%, 10 \%$, and $50 \%$ of trees treated with an insecticide). Ash density along urban roads was estimated from a variety of sources, including a recently developed survey that allows for rapid assessment of street tree compositions. Based on the $30 \mathrm{~km} / \mathrm{year}$ spread rate, a $4 \%$ discount rate, and a $10 \%$ treatment rate, the present value of the costs is estimated to be approximately CAD \$524 million (2010 currency rate); this value increases to roughly $\$ 890$ million when costs associated with backyard trees are included. These estimates are conservative because they focus only on damage to street (and backyard) trees; nonetheless, their magnitude suggests considerable justification for investments to slow the spread of EAB in Canada. Key Words. Agrilus planipennis; Canada; Cost-benefit Analysis; EAB Spread Model; Fraxinus; Urban Forest Management.
\end{abstract}

Emerald ash borer (EAB), Agrilus planipennis (Coleoptera: Buprestidae), is a metallic wood-boring beetle, native to Asia, that has destroyed millions of ash trees since being accidentally introduced to North America (Smith et al. 2009). During its larval stage, EAB feeds on the inner phloem and outer xylem of ash trees, leading to disrupted vascular flow and ultimately tree death (Cappaert et al. 2005). Once EAB becomes established in an area, about $30 \%$ of ash trees are killed each year (Herms et al. 2009a); very few host trees have shown any natural resistance, though blue ash (Fraxinus quadrangulata Michx.) and Asian ash species may be less susceptible (Anulewicz et al. 2007; Rebek et al. 2008). A number of insecticides have proven effective in protecting trees against EAB attack (Herms et al. 2009b; McKenzie et al. 2010); however, they are not likely to be widely applied because of considerations around cost, efficacy, and safety. Furthermore, EAB infestations are often difficult to detect until host trees show obvious signs of stress (McCullough et al. 2009), at which point it may be too late to reverse the damage (Herms et al. 2009b).

Since being introduced into southern Michigan in the early 1990s (Cappaert et al. 2005), EAB has spread rapidly across eastern and central North America, with outbreaks currently reported from 15 U.S. states and two Canadian provinces (USDA-APHIS 2011). Though a small percentage of mated females are capable of flying more than $20 \mathrm{~km}$ in 24 hours (Taylor et al. 2010), most larvae that originate from point source introductions are found within $100 \mathrm{~m}$ of adult emergence sites (Mercader et al. 2009). Thus, human-assisted dispersal via transport of infested ash material (Cappaert et al. 2005) and/or hitchhiking on vehicles (Buck and Marshall 2008) is likely the main cause of the ob- served EAB expansion (Prasad et al. 2010). Over time, EAB is expected to continue its advance across Canada and the United States, decimating ash in urban and rural settings along the way.

Given its rapid rate of spread and the prevalence of ash in both natural and urban forests across much of eastern and central North America (Burns and Honkala 1990; Woodall et al. 2009), EAB clearly has the potential to bring about significant economic and ecological impacts. Several studies have produced regional economic impact estimates in the U.S. (Kovacs et al. 2010; Sydnor et al. 2007; Sydnor et al. 2011). The objective of the current study was to report on efforts to generate EABrelated cost estimates for Canadian urban areas. The approach employs a relatively simple spread model to coarsely simulate EAB expansion to Canadian communities over a 30 -year period.

For each community in the study area, costs related to ash removal, replacement, and treatment are estimated and then discounted according to the timelines projected by the spread model. The lack of spatial data on ash distribution and abundance in Canada presents a significant challenge for this type of study. A variety of sources were used to estimate ash abundance along urban streets, including early results from a survey that allows rapid assessments of street tree composition. This research focused on street trees because they can be reliably and rapidly surveyed and are almost certain to require management action (i.e., removal/replacement or treatment) if attacked. This is an underestimation of total EAB impact.

Regulatory efforts to prevent the introduction of alien species to Canada and associated research are federal responsibilities, while long term management of established pests requires strong 
involvement of provincial ministries and municipalities. The Canadian Food Inspection Agency has regulatory authority over any new species entering the country, including the development of quarantine measures. The Canadian Forest Service is the federal government's lead in forest research with a strong capacity in forest insects and diseases. Provincial and territorial governments manage most of the forestlands in the country and therefore have a strong interest in alien species threats. Because of this the Canadian Forest Service is often engaged in monitoring and surveying efforts. Municipalities (and homeowners) manage removal, replacement, and treatment efforts in the urban setting-often bearing the financial burden of these frontline activities. All of these stakeholders have expressed the desire for more quantitative damage estimates to help justify mitigation activities.

\section{METHODS}

\section{Study Area and Associated Data}

This study was carried out for Canadian urban centers that fall within the natural geographic range of native ash (Fraxinus sp.) as defined by Little (1971) (Figure 1). Urban centers were identified using a digital version of Canada's urban areas cartographic boundary file (Statistics Canada 2007). For this coverage, an urban area is defined as having a population of at least 1,000 persons and a density of not fewer than 400 persons per square kilometer. There are 895 urban areas across Canada in this database; 641 of these fall within the native range of ash (Figure 1). The study is road based, so a digital version of the national road network was intersected with the urban areas boundary file to provide an estimate of the kilometers of road in each of these communities. A summary of the human population and road network in these communities is provided in Table 1.

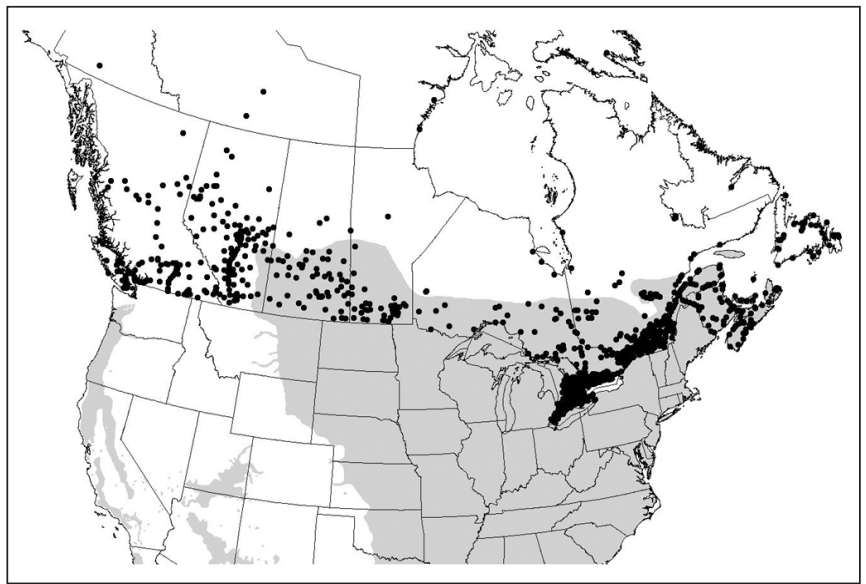

Figure 1. Geographical range of Fraxinus spp. (shaded) and locations of urban centers (dots) in Canada; urban centers falling within the shaded area were included in the current study.

\section{Estimating Urban Ash Component in Eastern Canada}

For estimating EAB impacts, the primary focus of the study authors was ash trees within $10 \mathrm{~m}$ of urban roadways ("street trees") as these trees would almost certainly require action (i.e., removal/replacement or treatment) if attacked. The cost for these actions would be borne by the municipality, utility company, or property owner depending on the specific location and/ or ownership of a given tree. The number of ash street trees were estimated using a variety of methods and data sources for both eastern and western Canada. Potential impacts to backyard trees were also included as an additional focus. There are other trees in the urban setting, such as those in parks and riparian areas, which could also have direct financial costs if attacked. Reliable data on these urban forest components are difficult to find, hence, not further considered at this stage.

The primary data source on ash abundance in eastern Canada is a survey that was developed to help rapidly assess the composition of street trees. Data currently exists for 16 urban centers in Ontario and New Brunswick, Canada (Table 2). Briefly, the survey protocol involves participants walking or driving routes $(0.5 \mathrm{~km}$ in length) randomly located throughout an urban center. Trees within $10 \mathrm{~m}$ of the road edge are identified and placed in coarse height classes $($ small $=1.5$ to $5.0 \mathrm{~m}$; medium $=5.0$ to 10.0 $\mathrm{m}$; large $=>10 \mathrm{~m}$ ). In total, the routes covered approximately $10 \%$ of the total length of roads in each urban center. While developing the survey, this level of coverage yielded reasonably accurate estimates of percent cover for major street tree species. From this data, the total number of trees per $\mathrm{km}$ of road was calculated, the percentage of those trees that were ash, and the percentage of ash in each size class (Table 2). The survey was web-based and random survey routes were generated for all 895 urban areas in Canada (contact the authors for further details). Surveys are ongoing that will enable further refinements to the results presented here and support other alien species risk analyses.

These tree survey data were augmented with information from existing tree inventories for Canadian urban centers, for example, information for three cities in eastern Canada (Table 2) from the Urban Forest Effects model (Nowak et al. 2010). This program was designed to collect forest composition data from urban areas in the U.S., but has been applied to several Canadian communities as well. Information for the city of St. Johns, Newfoundland, Canada (Table 2) (Environmental Design and Management, Ltd. 2006) was also obtained. All of these surveys were carried out to estimate tree species composition for the entire urban landscape. For this analysis it was assumed that the relative composition values were representative of trees within $10 \mathrm{~m}$ of city streets (i.e., definition of street trees).

A final source of information came from high resolution satellite imagery available through Google Maps. It was not possible to identify trees to the species level with this approach, but it was possible to count the total number of trees within 10

Table 1. The number of urban areas, the human population, road length, and estimated number of street ash found within the Canadian range of Fraxinus spp.

\begin{tabular}{lllllll}
\hline Region & Urban & Human & Road & & \multicolumn{2}{c}{ Estimated number of ash trees } \\
\cline { 4 - 7 } & areas $(\mathrm{N})$ & population & length $(\mathrm{km})$ & Small & Medium & Large \\
\hline Eastern Canada & 545 & $17,282,389$ & 86,477 & 138,363 & 216,193 & 190,250 \\
Western Canada & 96 & $1,510,706$ & 11,074 & 96,348 & 223,704 & 364,350 \\
Total & 641 & $18,793,095$ & 97,552 & 234,711 & 439,897 & 584,806 \\
\hline
\end{tabular}


Table 2. Street tree parameters used to estimate impact of EAB in eastern Canada.

\begin{tabular}{|c|c|c|c|c|c|c|c|c|c|}
\hline City & Province $^{z}$ & $\begin{array}{l}\text { Data } \\
\text { source }^{y}\end{array}$ & $\begin{array}{c}\text { Trees } / \mathrm{km} \\
\text { road }\end{array}$ & $\%$ Ash & $\begin{array}{c}\% \text { Ash } \\
<5 \mathrm{~m} \\
\text { tall }\end{array}$ & $\begin{array}{c}\% \text { Ash } \\
5-10 \mathrm{~m} \\
\text { tall }\end{array}$ & $\begin{array}{c}\% \text { Ash } \\
>10 \mathrm{~m} \\
\text { tall }\end{array}$ & $\begin{array}{l}\text { Ratio of } \\
\text { backyard to } \\
\text { front yard trees }\end{array}$ & $\begin{array}{c}\% \\
\text { house } \\
\text { frontage }\end{array}$ \\
\hline Bathurst & NB & $\mathrm{S}$ & 84.4 & 4.0 & 0 & 100 & 0 & - & - \\
\hline Bracebridge & $\mathrm{ON}$ & S & 185.7 & 0.0 & - & - & - & - & - \\
\hline Chatham & $\mathrm{ON}$ & $\mathrm{S}, \mathrm{G}$ & 115.9 & - & - & - & - & 0.75 & 62.7 \\
\hline Fredericton & NB & S & 123.0 & 0.0 & - & - & - & - & - \\
\hline Guelph & $\mathrm{ON}$ & $S, G$ & 112.7 & 6.3 & 8.1 & 16.2 & 75.7 & 1.21 & 82.7 \\
\hline Huntsville & $\mathrm{ON}$ & $\mathrm{S}$ & 164.4 & 1.5 & 0 & 0 & 100 & - & - \\
\hline Kitchener & $\mathrm{ON}$ & G & 95.7 & - & - & - & - & 0.98 & 74.1 \\
\hline London & $\mathrm{ON}$ & $\mathrm{S}$ & 97.1 & 3.3 & - & - & - & & \\
\hline Meaford & $\mathrm{ON}$ & $\mathrm{S}$ & 120.8 & 8.2 & 12.5 & 25.0 & 62.5 & & \\
\hline Moncton & NB & $\mathrm{S}$ & 72.1 & 0.1 & - & - & - & - & - \\
\hline Oakville & $\mathrm{ON}$ & $\mathrm{P}$ & - & 9.2 & - & - & - & & \\
\hline Ottawa - Gatineau & $\mathrm{ON}$ & G & 115.5 & - & - & - & - & 1.05 & 68.6 \\
\hline Oromocto & NB & $\mathrm{S}$ & 149.3 & 0.4 & - & - & - & - & - \\
\hline Sault Ste Marie & $\mathrm{ON}$ & $\mathrm{S}$ & 91.4 & 2.2 & 5.9 & 28.2 & 65.9 & & \\
\hline St. Johns & NFLD & $\mathrm{P}$ & - & 7.8 & - & - & - & & \\
\hline South Porcupine & $\mathrm{ON}$ & $\mathrm{S}$ & - & 1.7 & 0 & 36.3 & 63.6 & & \\
\hline Sudbury & $\mathrm{ON}$ & $\mathrm{S}$ & 59.0 & 4.9 & - & - & - & & \\
\hline Thunder Bay & $\mathrm{ON}$ & G & 76.8 & - & - & - & - & 1.08 & 54.4 \\
\hline Timmins & $\mathrm{ON}$ & $\mathrm{S}$ & 124.0 & 0.4 & - & - & - & - & - \\
\hline Toronto & $\mathrm{ON}$ & $\mathrm{P}$ & - & 7.8 & - & - & - & & \\
\hline Average $^{x}$ & & & 107.6 & 6.0 & 10.4 & 34.6 & 54.8 & 1.0 & 67.5 \\
\hline
\end{tabular}

${ }^{\mathrm{z}} \mathrm{NB}=$ New Brunswick; ON = Ontario; NS = Nova Scotia; NFLD = Newfoundland.

${ }^{\text {y }} \mathrm{S}=$ street tree survey; $\mathrm{G}=$ Google Maps; $\mathrm{P}=$ published values. See text for complete details.

${ }^{x}$ Average is weighted by population size of urban areas.

$\mathrm{m}$ of city streets. This was done for a total of 150 randomly located $0.5-\mathrm{km}$ street segments across six Ontario cities (Table 2). During this process, several other pieces of information were gathered. First, to estimate impacts in residential backyards, the number of trees in backyards were counted along the same 150 random street segments used to count street trees (Table 2 ). In cases where houses backed onto woodlots, making property lines difficult to distinguish, only trees within $10 \mathrm{~m}$ of the woodlot edge were counted, as these would have a higher likelihood of being treated or removed in the case of an EAB attack. The ratio of street trees to backyard trees was $1: 1$, suggesting that street tree costs could be doubled to include the backyard component. However, not all streets are fronted by dwellings with backyards (i.e., some are fronted by parks, industrial parks), thus the percentage of urban roads fronted by residential dwellings at the same 150 road segments was also estimated. Based on these estimates, backyard tree impacts are expected to be about $68 \%$ of those associated with street trees (Table 2).

\section{Estimating Urban Ash Component in Western Canada}

Different data sources were available for provinces in western Canada (e.g., Manitoba, Saskatchewan, and Alberta). The Forestry Branch of Manitoba Conservation provided a GIS database of an ash inventory that had been carried out for 16 urban centers in Manitoba. To make these data comparable to the street tree data for eastern Canada, the study authors selected only trees within a $10 \mathrm{~m}$ buffer of the road system in each community. Each tree in the database had a height attribute, and so were classified into the same height classes as those outlined for eastern Canada. The number of street ash per kilometer of road was cal- culated for each of the 16 communities by summing the number of street trees in each size class and then dividing each total by the length of the urban road system in that community (Table 3). Due to a lack of comparable data from other western provinces, these values were applied to Saskatchewan and Alberta as well.

There were notable differences in the relative abundance of ash in eastern and western Canada. In western Canada, there was an average of 8.7, 20.2, and 32.9 street ash $/ \mathrm{km}$ in the small, medium, and large size classes, respectively (Table 3); comparable numbers for eastern Canada were 1.6, 2.5, and 2.2 street ash $/ \mathrm{km}$ (calculated from Table 2). This approximately $8 \times$ higher inci-

Table 3. Number of small, medium, and large ash trees per kilometer of urban road for 16 communities in western Canada.

\begin{tabular}{llccc}
\hline Urban area & Province & \multicolumn{3}{c}{ Ash trees per km of urban road } \\
\cline { 3 - 5 } & & $<5 \mathrm{~m}$ tall & $5-10 \mathrm{~m}$ tall & $>10 \mathrm{~m}$ tall \\
\hline Manitou & Manitoba & 0.1 & 36.3 & 38.0 \\
Treherne & Manitoba & 11.1 & 31.2 & 46.6 \\
Altona & Manitoba & 10.6 & 35.6 & 51.2 \\
Beausejour & Manitoba & 6.3 & 8.7 & 16.1 \\
Carberry & Manitoba & 6.7 & 22.3 & 36.5 \\
Carman & Manitoba & 21.6 & 19.3 & 49.2 \\
Dauphin & Manitoba & 2.6 & 13.6 & 18.4 \\
Deloraine & Manitoba & 26.4 & 30.7 & 66.8 \\
Rivers & Manitoba & 8.8 & 4.2 & 16.6 \\
Selkirk & Manitoba & 3.9 & 10.0 & 15.1 \\
Souris & Manitoba & 11.5 & 27.7 & 44.7 \\
Steinbach & Manitoba & 9.5 & 24.3 & 39.8 \\
Stonewall & Manitoba & 7.6 & 7.7 & 16.3 \\
Virden & Manitoba & 9.0 & 11.2 & 23.0 \\
Winkler & Manitoba & 23.0 & 48.7 & 79.6 \\
Portage La Prairie & Manitoba & 2.8 & 13.6 & 19.0 \\
Average $^{z}$ & & 8.7 & 20.2 & 32.9 \\
\hline
\end{tabular}

${ }^{\mathrm{z}}$ Average is weighted by population size of urban areas. 
dence of ash in western Canada was supported by two sources: 1) Google Maps counts of street trees at 16 random locations in four Manitoba communities indicated that there were about twice as many street trees in Manitoba than Ontario, and 2) street tree composition data for the city of Saskatoon, Saskatchewan (Geoff McLeod, pers. obs.) indicated that about 25\% of street trees were ash, approximately $4 \times$ that of eastern Canada. This pattern is perhaps not surprising given the more limited number of tree species that can tolerate the somewhat more extreme climate found in the prairies region (McKenney et al. 2007).

\section{Predicting EAB Spread}

The Canadian Forest Service Forest Bioeconomic Model (CFSFBM) was used as the basic modeling framework for projecting EAB spread over time. The model shares conceptual similarities with the spread model described by Yemshanov et al. (2009a), Yemshanov et al. (2009b), and Koch et al. (2009). Briefly, CFSFBM provides a grid-based modeling framework for simulating a variety of processes in a spatial setting, including the spread, establishment, and impact of alien species. For example, the model has been used to examine potential wood supply impacts from Sirex noctilio, an invasive alien wasp species (Koch et al. 2009; Yemshanov et al. 2009a; Yemshanov et al. 2009b).

A simplified version of CFS-FBM was used to obtain a coarse depiction of how EAB might spread across the country. The approach required a spread probability-density function, or 'kernel,' which determined the probability of EAB spread as a function of the geographic distance to locations with known EAB infestations. Published EAB spread rates vary by more than two orders of magnitude, reflecting the highly variable spread of EAB under different conditions. The smallest reported value $(30 \mathrm{~m} / \mathrm{yr})$ was for a new infestation starting from a single source (a pile of infested logs) with many ash trees in the near vicinity (Mercader et al. 2009). In contrast, Kovacs et al. (2010) reported an average spread rate of $16 \mathrm{~km} / \mathrm{yr}$ based on spread data in Michigan, U.S., over the period 1994-2009. Similarly, Smitley et al. (2008) reported a rate of $10.6 \mathrm{~km} / \mathrm{yr}$ for the spread rate of detectable symptoms for an outbreak in southeastern Michigan over the period 2003-2006. These larger estimates are based on data that include natural long distance dispersal events that may be induced by high population density and/or low host availability, as well as regionalscale, human-assisted movements (such as trade and transportation). Based on comparison to observed rates of spread in southern Ontario, the spread rate reported by Smitley et al. (2008) was adopted as a baseline value for the current study.

The spread model simulations covered an area extending from maritime Canada in the east to Alberta in western Canada with a map cell resolution of $\sim 1 \mathrm{~km}^{2}$. The model employed a negative exponential function to determine the probability, $\mathrm{p}$ that a cell would become infested as a function of its distance, $\mathrm{d}$ from the nearest infested cell:

[1]

$$
p=e^{-0.0943 d}
$$

The value of the exponent in Equation 1 (i.e., 0.0934) was determined such that the mean distance defined by the equation is $10.6 \mathrm{~km}$ (i.e., the desired average spread rate as previously outlined). To address the wide variation in potential spread rate, the model was run with three different maximum spread values to represent slow, medium, and fast linear rates of spread corresponding to approximately 10,30 , and $50 \mathrm{~km} /$ year. The maximum spread value truncates the negative exponential probability-density function, thus placing an upper limit on the extent of annual spread - a key factor controlling overall spread rates and patterns (Koch et al. 2009; Yemshanov et al. 2009a; Yemshanov et al. 2009b). This approach produced a uniform spread pattern that predicted consistent arrival times that were not influenced by rare (and highly uncertain) long-distance dispersal events.

The model was run over a 30-year time horizon to generate expected arrival times for EAB at each map cell in the study area. The model was initiated from known Canadian and U.S. EAB occurrence locations as of 2009 (USDA-APHIS 2011). An implicit assumption was that any cell that fell within the study area contained at least some ash that could be a host (and hence pathway) for colonization. This assumption was necessary because, as previously noted, detailed spatial data of ash abundance were not available in Canada; furthermore, ash is considered relatively common throughout its native Canadian range (Farrar 1995).

\section{Unit Cost Estimates for EAB Damage}

Four types of costs were explicitly incorporated into this study: removal costs, replacement costs, treatment costs, and what were termed as community overhead costs (Table 4). All cost estimates are in year 2010 Canadian dollars and based on a combination of published values from the United States. (Kovacs et al. 2010) and personal communications with City Foresters in Windsor, Toronto, Oakville, London, Ottawa, and Thunder Bay, Ontario; and Saskatoon.

It was assumed that all ash street trees, as defined in this study, required either removal or treatment. Removal costs vary widely according to tree size (height and diameter), location (e.g., proximity to buildings, and power and telephone lines), and contractor rate; the cost estimates attempted to describe an average cost for small, medium, and large trees (Table 4). Replacement costs are also highly variable and depend on the size and source of the planting stock; the estimate of CAD $\$ 400$ is representative of the per tree costs incurred by municipalities when planting well established (i.e., $\sim 4 \mathrm{~cm}$ in diameter) saplings. It was posited that only a certain percentage of removed trees would actually be replaced; in lieu of data on this subject, a $50 \%$ replacement rate was assumed.

Insecticide treatments were incorporated into the model as an alternative to cutting large and medium sized trees. Three plausible treatment scenarios were considered: 1) no treatments; 2) a modest treatment rate, where $10 \%$ of large and medium trees were treated; and 3) a high treatment rate, where $50 \%$ of large and medium trees were treated. Currently, the main product used in Canada for protecting trees against EAB attack is TreeAzin ${ }^{\mathrm{TM}}$ (McKenzie et al. 2010). Treated trees were tracked in a separate cost stream that received ongoing biannual treatments for the remainder of the simulation; cost estimates were based on reported costs associated with TreeAzin for large and medium trees (Table 4).

Community overhead costs are intended to represent considerations such as staff time to manage and coordinate the response, communication costs, monitoring and surveillance costs, and disposal operations for tree waste. Based on discussions with city 
Table 4. Model parameters and probability distributions used in the sensitivity analysis of EAB economic impacts. Currency is expressed in 2010 Canadian dollars.

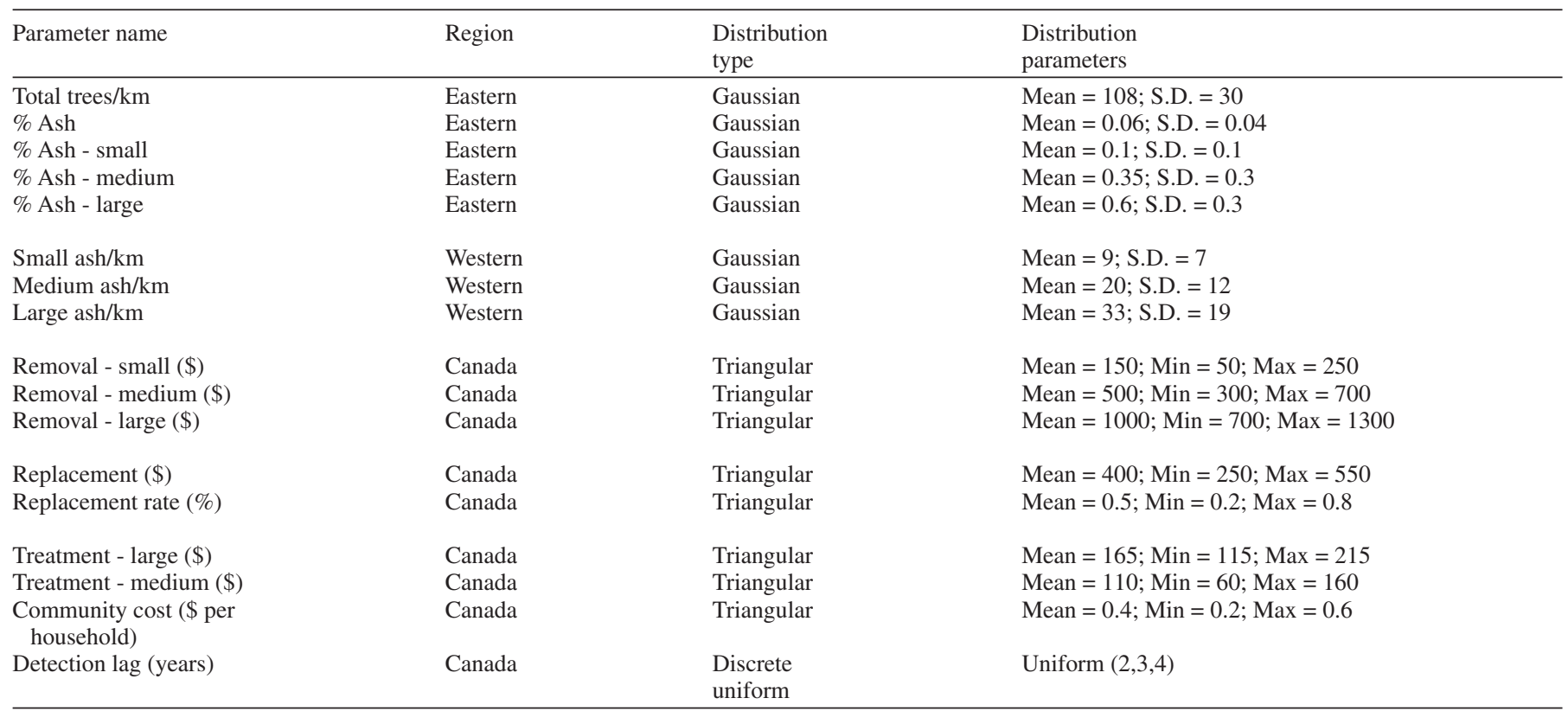

foresters, it was estimated that these costs would be approximately $\$ 0.40 /$ household - applied in each year that an outbreak was ongoing in a given city. The number of households in each community was obtained from Statistics Canada (Statistics Canada 2007).

Three different positive discount rates were employed: $2 \%$, $4 \%$, and $10 \%$. These rates reflect different perspectives on the value of delaying payment for incurred costs. In addition, results are presented with no discounting (a zero discount rate), to demonstrate the effect of discounting. Some economists provide theoretical arguments that very low discount rates are justifiable when significant intergenerational outcomes are at stake; species losses could arguably be taken as one such outcome (Weitzman 1994; Portney and Weyant 1999). For the positive discount rates, the authors also report the cost estimates in equivalent annual dollars (see Boardman et al. 2001).

\section{Model Scenarios and Sensitivity Analysis}

The model was run for 36 different combinations of spread rate (slow, medium, and fast), treatment rate $(0 \%, 10 \%$, and $50 \%)$, and discount rate $(0 \%, 2 \%, 4 \%$, and $10 \%)$. As with any model, there was uncertainty in the input parameters; to address this, 100 Monte Carlo simulations were run for each of the 36 scenario combinations using the @ Risk software package (Pallisade Corporation 2002). During each simulation, the value for each input parameter was drawn from a user-defined distribution of possible values. Since there were multiple estimates of the tree composition parameters for eastern and western Canada, a Gaussian distribution for each parameter was defined using mean and standard deviation values calculated from the data (Table 4). Due to the relatively small amount of empirical data behind the remaining input parameters, they were assigned a triangular distribution for the Monte Carlo simulations. This distribution requires knowledge of mean, min, and max values, and assumes only a simple triangular shape. Plots of cumulative mean cost against simulation number indicated that 100 replications were adequate for this analysis.
The influence of each input parameter listed in Table 4 on regional and total EAB economic impact was estimated using a regression approach (Pallisade Corporation 2002). For this analysis, each iteration of the simulation produced an observation for a multiple regression model with cost as the dependent variable and the input parameters as the independent variables. The standardized slope coefficient associated with each input parameter was taken as its measure of influence.

\section{RESULTS}

\section{Overall Economic Impact}

Approximately 545,000 and 684,000 ash street trees were estimated in eastern and western Canada, respectively, for a total of $\sim 1.2$ million ash street trees across the 641 communities included in the study area (Table 1). Estimated impacts for the 30-year time horizon ranged from $\$ 265$ million to $\$ 1,177$ million depending on the combination of spread, treatment, and discount rates (Table 5). The low estimate resulted from the slow spread rate, $10 \%$ discount rate, and 50\% treatment rate; the high estimate resulted from the fast spread rate, $0 \%$ discount rate and $50 \%$ treatment rate. Figure 2 shows cost accumulation through time for selected spread and treatment rates. These estimates are for street trees only; the inclusion of expenses associated with backyard trees can be roughly estimated by multiplying the values in Table 5 by a factor of 1.7 , bringing the range to $\$ 451$ million to $\$ 2,001$ million. Total costs associated with a "middle-of-the-road" scenario (i.e., medium spread rate, $10 \%$ treatment rate, and $4 \%$ discount rate) were $\$ 524$ million; this would increase to roughly $\$ 890.8$ million if expenses related to backyard trees were included.

As would be expected, faster spread rates were associated with higher economic impacts (Table 5). For example, total street tree costs ranged from $\$ 265$ million to $\$ 506$ million (at positive discount rates) for the slow spread rate compared, to $\$ 371$ million to $\$ 820$ million for the fast spread rate (Table 5). These 
differences stemmed from the number of communities attacked over the 30-year time horizon under the fast (634 communities attacked) and slow (386 communities attacked) spread scenarios. In fact, based on the slow spread rate, the infestation had not reached western Canada by the end of the simulation period (Table 5). This is evident in Figure 2, where there is an obvious rise in costs mid-to-late in the simulation under the me-

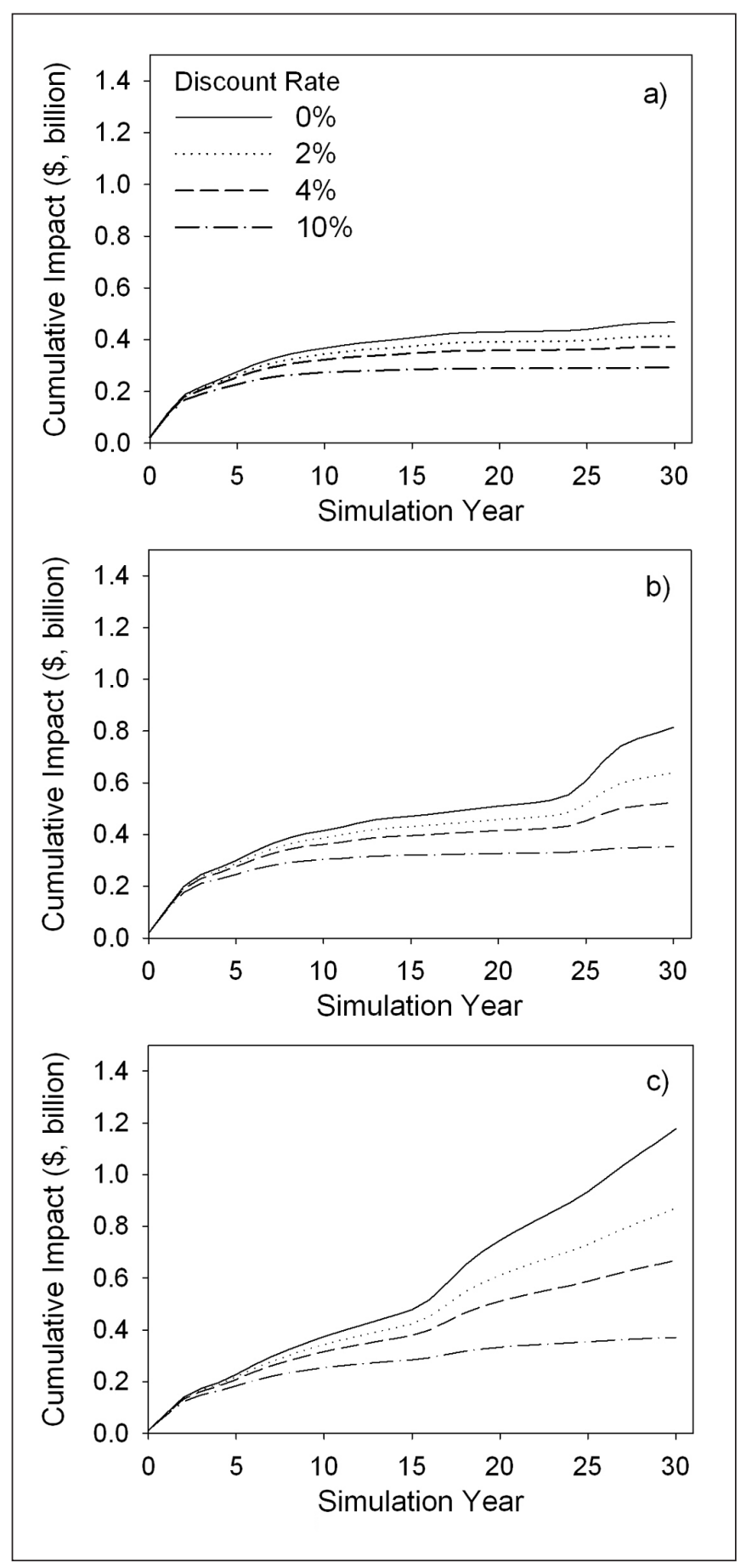

Figure 2. Mean economic impact of EAB over time, based on three scenarios: a) slow spread rate and $0 \%$ of ash trees treated, b) medium spread rate and $10 \%$ of ash trees treated, and c) fast spread rate and $50 \%$ of ash trees treated. dium and fast spread rates due to the arrival of EAB at cities in western Canada (particularly Winnipeg, Manitoba); a similar pattern does not appear under the slow dispersal rate. This result is largely driven by the high ash abundance in western communities. There is, of course, an inverse relationship between the present value of the cost estimates and the discount rate. For example, a $2 \%$ discount rate resulted in costs ranging from $\$ 413$ million to $\$ 870$ million, while a $10 \%$ discount rate produced costs ranging from $\$ 265$ million to $\$ 422$ million (Table 5). Higher discount rates effectively reduce the present value of future costs. The influence of discount rate was also apparent in Figure 2 where the low discount rate was associated with higher costs, particularly under the fast spread rate and 50\% treatment rate; conversely, the high discount rate resulted in considerably lower costs and relatively little difference in cost projections between scenarios. Note however that the equivalent annual cost estimates in Table 5 increase as the discount rate increases. While this may seem counterintuitive, it is a standard result because present values of annuities decrease as interest rates increase and increase when interest rates decline (see Boardman et al. 2001).

As might be expected, increased treatment rates had higher overall costs for the $0 \%, 2 \%$, and $4 \%$ discount rates; however, this pattern was reversed under the $10 \%$ discount rate (Table 5). This result is particularly sensitive to the time horizon of the simulation and the spatiotemporal pattern of the spread. Many large urban centers in eastern Canada (e.g., Toronto, Ontario; Montreal, Quebec) were attacked very early in the simulation, thus a large pool of trees accumulated substantial treatment costs by the end of the 30-year period. Since treatment costs are accumulated through time, they are also strongly influenced by the discount rate. For example, under a medium spread rate and $0 \%$ discount rate, treating $50 \%$ of trees resulted in a total cost of $\$ 914$ million; for the same spread and treatment rates, this value dropped to $\$ 318$ million under a $10 \%$ discount rate (Table 5).

\section{Sensitivity Analysis}

Table 5 also presents standard deviations of the cost distributions for each scenario based on the Monte Carlo simulations. Standard deviation values were generally within $40 \%$ of the mean, indicating that the impact estimates are relatively robust to plausible changes in the input parameter values. In eastern Canada, estimated costs were strongly affected by the proportion of ash and the number of trees per unit of road length (Figure 3a). Costs associated with removal, replacement, and treatment of large and/or medium trees made up most of the remaining significant input parameters. Detection lag had a relatively minor, negative impact on cost estimates in eastern Canada. Higher lag values meant that $\mathrm{EAB}$ attacks were detected later, resulting in lower discounted costs or, for grid cells attacked very late in the simulation, costs being pushed outside the 30 -year time horizon.

In western Canada, the most influential parameter on final cost estimates was the number of large trees $/ \mathrm{km}$ (Figure $3 \mathrm{~b}$ ). Detection lag had a much stronger influence in the west; since many western communities were attacked very late in the simulation, any increase in the detection lag resulted in a significant number of grid cells being excluded from the 30 -year analysis. Costs associated with removal, replacement, and treatment of large and/or medium trees made up most of the remaining sig- 
Table 5. Estimated economic impacts (mean and standard deviation) of EAB on street trees in Canada over a 30 -year time horizon. Equivalent annual values are shown in parentheses. Currency is expressed in 2010 Canadian dollars.

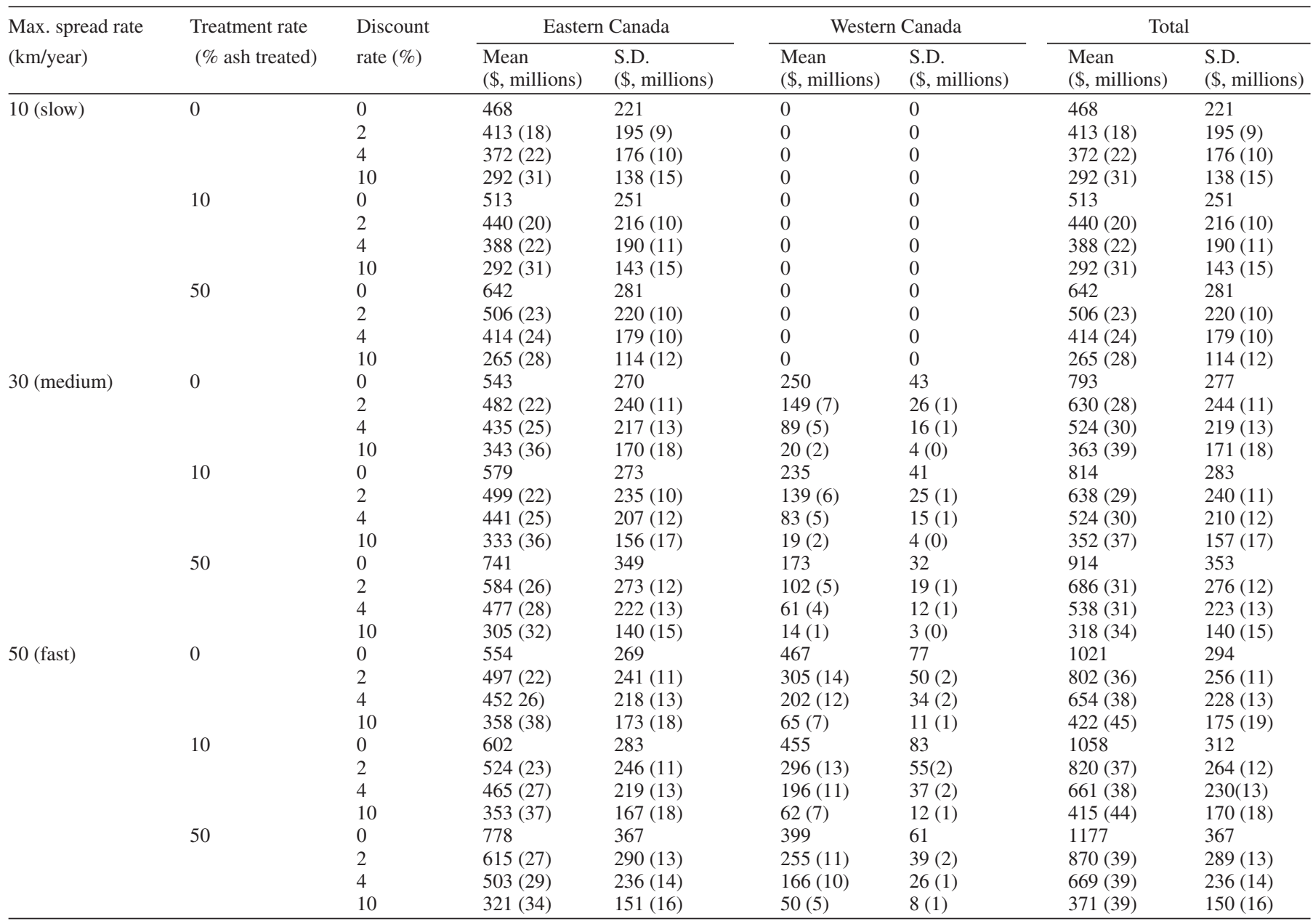

nificant input parameters. For all of Canada, the percentage of ash street trees and the number of street trees per kilometer of road were the most influential input parameters (Figure 3c).

\section{Impacts on Specific Urban Areas}

The 10 cities showing the greatest EAB-related impacts differed depending on the spread and discount rates (Table 6). Toronto, Ontario; Montreal, Ottawa-Gatineau, and Quebec City, Quebec; and Hamilton, Ontario, were consistently among the most heavily affected cities with losses of roughly $\$ 100$ million predicted for Toronto and Montreal under each of the scenarios shown in Table 6. As noted, under the slow spread rate, no western communities were attacked within the simulation timeframe. However, under the faster spread rates, Winnipeg, Manitoba, was projected to experience some of the heaviest EAB-related losses - nearly \$200 million in undiscounted cashflow equivalent. Other cities in western Canada, such as Brandon, Manitoba, and Regina and Moose Jaw, Saskatchewan, also make the list when costs are not discounted. These western communities are much smaller than some of the eastern communities that appear in Table 6, but involve comparable costs due to the considerably higher abundance of ash along urban streets. The impact of discounting is large in western communities because they are generally attacked late in the simulation period.

\section{DISCUSSION}

It was estimated that, over a 30 -year time horizon, the discounted financial costs of EAB on urban street trees in Canada may range from about $\$ 0.3$ to $\$ 0.9$ billion; when backyard trees are included, the range of projected impacts increases to approximately $\$ 0.5$ to $\$ 1.5$ billion. Kovacs et al. (2010) estimated an economic impact of $\$ 10.7$ billion (using a $2 \%$ discount rate) for $\mathrm{EAB}$ in urban areas of 25 eastern U.S. states. There are a number of differences between the studies that help explain the disparity in the magnitude of these estimates. The population base covered by the Kovacs et al. (2010) study is about $8 \times$ that of the current study; and since urban costs are closely related to population size, this explains much of the difference. Furthermore, Kovacs et al. (2010) estimated the economic impacts associated with all ash trees in communities, as opposed to only street (and backyard) trees in the current study. When these factors are taken into consideration, the estimates are very comparable.

Using a different approach, Sydnor et al. (2007) estimated removal and replacement costs of $\$ 1$ to $\$ 4.2$ billion for the state of Ohio alone, with costs increasing to $\$ 1.8-\$ 7.6$ billion when tree-related benefits such as shading, stormwater mitigation, pollution abatement, and property values were included in the calculation. In a related study, Sydnor et al. (2011) estimated removal and replacement costs of \$5.7-\$11 billion for 


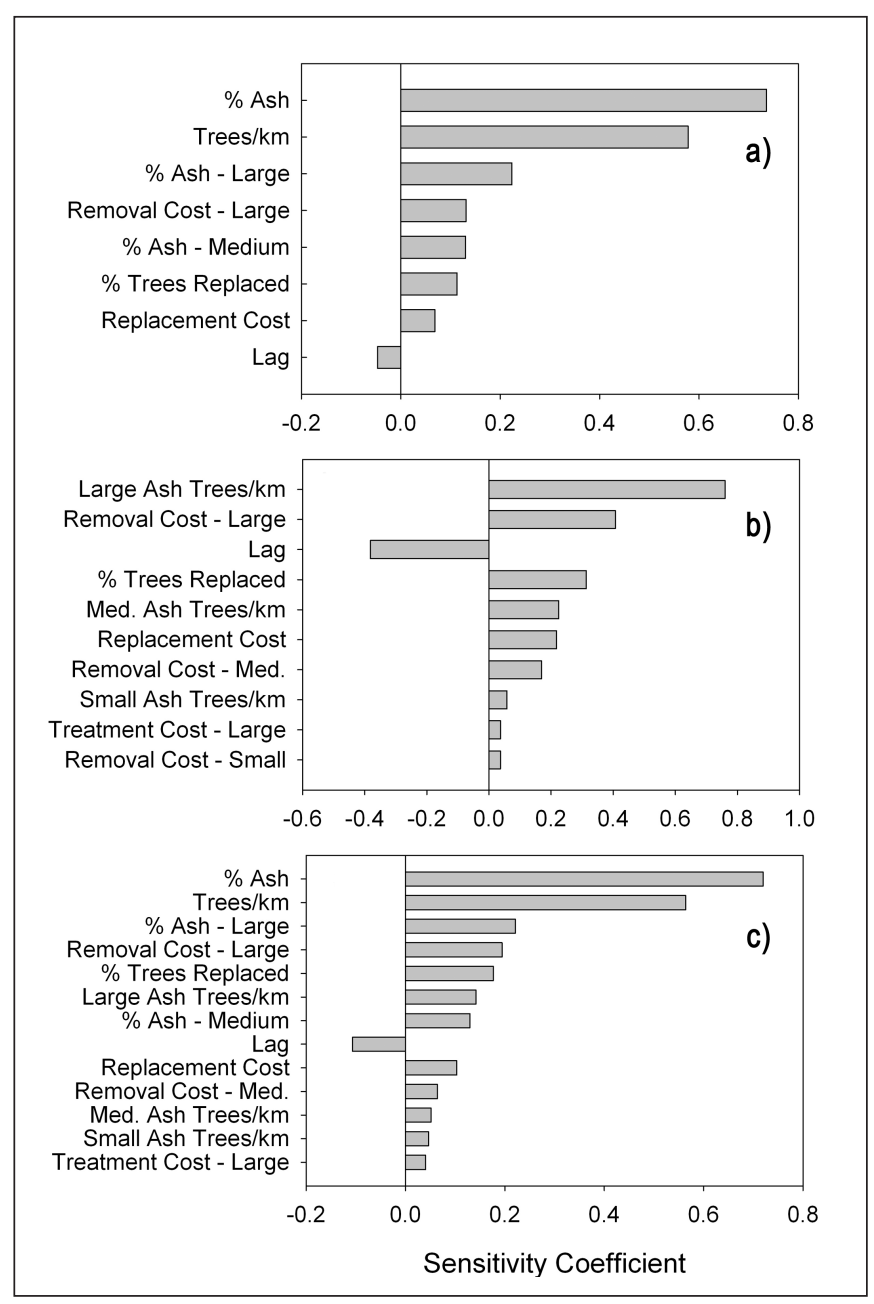

Figure 3. Sensitivity of EAB economic impact estimates to model parameter values for: a) eastern Canada, b) western Canada, and c) the entire study area. The sensitivity coefficients were generated using a regression approach; larger values indicate more influence on the impact estimates.

communities in four midwestern states, with costs increasing to \$13.4-\$26 billion when the extended benefits were considered. Even after accounting for population size differences, their removal and replacement estimates are about three times higher than those reported here. Again, this is partly explained by the inclusion of all street, private, and park trees in their estimates. Another major difference is that Sydnor et al. $(2007 ; 2011)$ did not incorporate spread dynamics, and hence economic discounting considerations, into their estimates. As demonstrated here, discounting can have a major impact on cost estimates. This variation demonstrates the wide range in projected costs that can result from (sometimes subtle) methodological differences between impact studies and underlines the importance of exploring multiple approaches to such work.

The estimates provided here are conservative in a number of ways, focusing on direct financial costs associated with street (and backyard) tree management. While this represents an important and more readily quantifiable portion of EAB impacts, there are a number of other direct financial considerations that warrant mention. These estimates do not include costs related to trees in parks and urban woodlands. Though the number of ash in these land use categories can be substantial (Nowak et al. 2010), there is significant difficulty finding reliable estimates of ash density for them. Furthermore, it is not clear what percentage of ash trees in the parklwoodland setting would pose safety risks and thus require management action. These estimates also ignore costs associated with ash trees in smaller towns and rural residential settings - again, due to data availability. Finally, it should be recognized that ash trees do exist in urban centers outside the native range of ash, which could significantly add to the cost of EAB in Canada [e.g., 5.3\% of municipal trees in Vancouver, British Columbia, are ash (McManus, pers. comm.)]. However, pathways and spread rates into these areas are highly uncertain.

Many other benefits have been attributed to urban trees, including home value premiums, energy savings, pollution and runoff reduction, and human health benefits (Dwyer et al. 1992). These benefits have been quantified for various locations, allowing approximate economic values to be attached to urban trees (e.g., McPherson et al. 2007). Including the loss of these benefits would clearly increase the economic impact attributed to EAB. In fact, EAB cost estimates provided by Sydnor et al. (2007) and Sydnor et al. (2011) approximately doubled when these "landscape values" were included in their calculations. These benefits were not incorporated here because widely accepted values do not exist for Canada and published values are situation dependent (McPherson et al. 2007). Nevertheless, the incorporation of such values could be the subject of future efforts.

Losses in timber sales would also be expected as a result of an EAB invasion (Schwan and Elliott 2010). However, detailed spatial data on ash volumes are not available for much of Canada, making it very challenging to estimate potential harvest losses in the natural forest setting. Ash also plays an important ecological role in many southern Canadian ecosystems. For instance, ash is a common riparian species and its loss will likely effect water quality for both wildlife and humans (Kreutzweiser 2010). Furthermore, the loss of ash could have a major impact on biodiversity in agricultural landscapes of southern Ontario, where it is often a key component of remnant forest woodlots (Schwan and Elliott 2010). While these ecosystem services are extremely challenging to include in an economic analysis, they are mentioned here to emphasize the extent to which this assessment underestimates the full impact of this invasive alien species.

For the three lower discount rates, costs increased as treatment rate increased; this pattern was reversed at the $10 \%$ discount rate. This finding suggests, for example, municipalities/homeowners that have high borrowing costs should consider treating a portion of their trees because this results in a series of smaller, delayed payments compared to large scale removal and replacement efforts (McKenney and Pedlar 2012). Even at lower discount rates, the opportunity to spread removal costs over time through the use of treatments may be appealing to some municipalities. These results provide a simple approximation of how overall costs may vary under different treatment rates. However, it is important to note that decisions to treat versus remove trees can be complex and involve not only relatively straightforward considerations such as treatment, removal, and replacement costs, but also more subtle factors like the influence of tree cover on property values, energy budgets, and pollution control. Recent studies have examined this topic from the perspective of both individual homeowners (McKenney and Pedlar 2012) and municipalities (Sadof et al. 2011).

Additionally, these results may be roughly interpreted to support slow-the-spread efforts against EAB. If the medium or fast spread rate models are deemed to be more indicative of likely outcomes, then the cost differences between the slow versus me- 
Table 6. Canadian cities projected to show the greatest economic impact from EAB invasion over the next 30 years; ten cities are listed for each of three spread rates and two discount rates. Currency is expressed in Canadian dollars.

\begin{tabular}{|c|c|c|c|c|}
\hline \multirow{2}{*}{$\begin{array}{l}\text { Max. spread rate } \\
(\mathrm{km} / \text { year) }\end{array}$} & \multicolumn{2}{|c|}{$0 \%$ Discount rate } & \multicolumn{2}{|c|}{$4 \%$ Discount rate } \\
\hline & City & $\begin{array}{l}\text { Impact } \\
(\$, \text { millions })\end{array}$ & City & $\begin{array}{l}\text { Impact } \\
(\$, \text { millions })\end{array}$ \\
\hline \multirow[t]{8}{*}{10 (slow) } & Toronto & 96 & Toronto & 85 \\
\hline & Ottawa - Gatineau & 27 & Ottawa - Gatineau & 24 \\
\hline & Québec & 23 & Hamilton & 18 \\
\hline & Hamilton & 20 & St. Catherines - Niagara & 13 \\
\hline & St. Catherines - Niagara & 15 & Kitchener & 9 \\
\hline & Windsor & 10 & London & 9 \\
\hline & London & 10 & Québec & 8 \\
\hline & Oshawa & 8 & Oshawa & 7 \\
\hline \multirow[t]{8}{*}{30 (medium) } & Winnipeg & 161 & Toronto & 85 \\
\hline & Toronto & 97 & Montréal & 78 \\
\hline & Montréal & 93 & Winnipeg & 58 \\
\hline & Ottawa - Gatineau & 27 & Ottawa - Gatineau & 24 \\
\hline & Québec & 25 & Hamilton & 18 \\
\hline & St. Catherines - Niagara & 15 & Kitchener & 10 \\
\hline & Kitchener & 13 & Windsor & 9 \\
\hline & Windsor & 10 & London & 9 \\
\hline \multirow[t]{10}{*}{50 (fast) } & Winnipeg & 172 & Toronto & 85 \\
\hline & Toronto & 96 & Winnipeg & 84 \\
\hline & Montréal & 92 & Montréal & 78 \\
\hline & Regina & 53 & Ottawa - Gatineau & 24 \\
\hline & Ottawa - Gatineau & 27 & Regina & 19 \\
\hline & Québec & 25 & Hamilton & 18 \\
\hline & Moose Jaw & 23 & Québec & 17 \\
\hline & Brandon & 22 & St. Catherines - Niagara & 13 \\
\hline & Hamilton & 20 & Brandon & 10 \\
\hline & St. Catherines - Niagara & 15 & Kitchener & 10 \\
\hline
\end{tabular}

dium and fast spread models are suggestive of potential benefits for slowing the spread of EAB. The difference in annual costs between the slow and medium spread rate models are between $\$ 6$ million/year and \$10 million/year (derived from the differences in the annuity values shown in Table 5). Cost differences are of course higher for the slow versus fast rate models $(\$ 11-$ $\$ 18$ million/year). Notably in slow rate models, western Canada has not been affected in the 30-year simulation period. Clearly the arbitrary cut-off of a 30-year time horizon does affect these results but with higher discount rates (e.g., 10\%), this effect is lessened simply because of the strong effect of discounting over that length of time. At the $10 \%$ discount rate, the differences between the fast and slow spread rate models range from about $\$ 11$ to $\$ 14$ million/year ( $\$ 3$ to $\$ 7$ million/year for the medium versus slow spread rate). Annual expenditures up to these levels to slow the spread of EAB would be justified on economic efficiency grounds if indeed they were judged to be effective.

\section{CONCLUSION}

EAB-related street tree damage was estimated in the study area over a 30-year time horizon to range from $\$ 265$ million to $\$ 1,177$ million depending on the combination of spread, treatment, and discount rates ( $\$ 451$ million to $\$ 2,001$ million with backyard trees included). Based on a medium spread rate, $10 \%$ treatment rate, and 4\% discount rate, estimated costs were \$524 million; this value increased to $\$ 891$ million when costs were extended to include backyard trees. Cast in equivalent annual values, these estimates range from $\$ 18$ million/year (2\% discount rate, slow spread, and no treatments) to $\$ 45$ million/year (10\% discount rate, fast spread, and no treatments). Including backyard trees would increase these annual equivalents to $\sim \$ 31$ million and $\$ 77$ million per year. Though conservative, these estimates are comparable to a similar study carried out in the U.S. (Kovacs et al. 2010), once differences in population size and study scope are taken into account. Community-specific cost estimates can be obtained by contacting the corresponding author.

These findings can provide some justification for slow-thespread initiatives, such as early detection surveys and wood movement laws. However, the net value of a slow-the-spread program depends on two major considerations: 1) the extent to which it delays EAB arrival at a given urban centre, and 2) the perceived time value of expenditures as influenced by the discount rate. Nevertheless, even just the simple notion of preserving ash in communities for future generations may be an important consideration for some decisionmakers, especially if EAB proves to be as devastating as some believe. Given the magnitude of the damage estimates provided here, there is also considerable economic justification for ongoing research efforts to better understand and manage EAB.

Acknowledgements. We thank: Irene Pines, Robert McMahon, and others at Manitoba Conservation for generously sharing their ash survey data; the Ontario Stewardship Rangers and all other volunteers who have helped to collect street tree data in eastern Canada; and Geoff McLeod, Bill Roesel, Jason Pollard, John McNeil, and Richard Ubbens for feedback on tree removal and replacement costs. We also thank two anonymous reviewers for their comments. Any errors remain the responsibility of the authors. 


\section{LITERATURE CITED}

Anulewicz, A.C., D.G. McCullough, and D.L. Cappaert. 2007. Emerald ash borer (Agrilus planipennis) density and canopy dieback in three North American ash species. Arboriculture \& Urban Forestry $33: 338-349$

Buck, J.H., and J.M. Marshall. 2008. Hitchhiking as a secondary dispersal pathway for emerald ash borer, Agrilus planipennis. The Great Lakes Entomologist 41:197-199.

Burns, R.M., and B. H. Honkala, technical coordinators. 1990. Silvics of North America: 2. Hardwoods. Agriculture Handbook 654. Washington D.C.: U.S. Department of Agriculture, Forest Service. Vol. 2, 877 pp.

Cappaert, D., D.G. McCullough, T.M. Poland, and N.W. Siegert. 2005. Emerald ash borer in North America: a research and regulatory challenge. American Entomologist 51:152-165.

Dwyer, J. F., E.G. McPherson, H.W. Schroeder, and R.A. Rowntree. 1992. Assessing the benefits and costs of the urban forest. Journal of Arboriculture 18:227-234.

Environmental Design and Management Ltd. 2006. St. John's urban forest management master plan. City of St. John's, Newfoundland, Canada. 71 pp.

Farrar, J.L. 1995. Trees in Canada. Fitzhenry and Whiteside Lmt. 502 pp.

Herms, D.A., K.J.K. Gandhi, A. Smith, J. Cardina, K.S. Knight, C.P. Herms, R.P. Long, and D.G. McCullough. 2009a. Ecological impacts of emerald ash borer in forests of southeast Michigan. pp. 36-37. In: K.A. McManus and K.W. Gottschalk. Proceedings. 20th U.S. Department of Agriculture interagency research forum on invasive species 2009. Gen. Tech. Rep. NRS-P-51. Newtown, PA, U.S. Department of Agriculture, Forest Service, Northern Research Station.

Herms, D.A., D.G., McCullough, D.R. Smitley, C.S. Sadof, R.C. Williamson, and P.L. Nixon. 2009b. Insecticide options for protecting ash trees from emerald ash borer. North Central IPM Center Bulletin. 12 pp.

Koch, F.H., D. Yemshanov, D.W. McKenney, and W.D. Smith. 2009. Evaluating critical uncertainty thresholds in a spatial model of forest pest invasion risk. Risk Analysis 29:1227-1241.

Kovacs, K.F., R.G. Haight, D.G. McCullough, R.J. Mercader, N.W. Siegert, and A.M. Liebhold. 2010. Cost of potential emerald ash borer damage in U.S. communities, 2009-2019. Ecological Economics 69:569-578.

Kreutzweiser, D. 2010. Ecological implications of emerald ash borer infestations and management. pp. 18-21. In: D.B. Lyons and T.A. Scarr. Workshop Proceedings: Guiding Principles for Managing the Emerald Ash Borer in Urban Environments. Natural Resources Canada. 44 pp.

Little, E.L. Jr. 1971. Atlas of United States Trees, vol. 1: Conifers and Important Hardwoods. Washington (D.C.): U.S. Department of Agriculture. Miscellaneous publication no. 1146.

McCullough, D.G., T.M. Poland, and D. Cappaert. 2009. Attraction of the emerald ash borer to ash trees stressed by girdling, herbicide treatment or wounding. Canadian Journal of Forest Research 39:1331-1345.

McKenney, D.W., and J.H. Pedlar. 2012. To treat or to remove: An economic model to assist homeowners in deciding the fate of ash trees threatened by emerald ash borer. Arboriculture \& Urban Forestry, in press.

McKenney, D., J.H.Pedlar, K. Lawrence, K. Campbell, and M. Hutchinson. 2007. Beyond traditional hardiness zones: Using climate envelopes to map plant range limits. BioScience 57:929-937.

McKenzie, N., B. Helson, D. Thompson, G. Otis, J. McFarlane, T. Buscarini, and J. Meating. 2010. Azadirachtin: an effective systemic insecticide for control of Agrilus planipennis (Coleoptera: Buprestidae). Journal of Economic Entomology 103:708-717.

McPherson, G.E., J.R. Simpson, J.J. Peper, S.L. Gardner, K.E. Vargas, and Q. Xiao. 2007. Northeast community tree guide: benefits, costs, and strategic planting. Gen. Tech. Rep. PSW-GTR-202. Albany, CA: U.S. Department of Agriculture, Forest Service, Pacific Southwest Research Station. 106 pp.

Mercader, R.J., N.W. Siegert, A.M. Liebhold, and D.G. McCullough. 2009. Dispersal of the emerald ash borer, Agrilus planipennis in newly-colonized sites. Agricultural and Forest Entomology 11:421-424.

Nowak, D.J., R.E. Hoehn III, D.E. Crane, J.C Stevens, and C.L. Fisher. 2010. Assessing urban forest effects and values, Chicago's urban forest. Resour. Bull. NRS-37. Newtown Square, PA: U.S. Department of Agriculture, Forest Service, Northern Research Station. 27 pp.

OMNR. 2010. Annual Report on Forest Management 2008/09. Queen's Printer for Ontario.

Pallisade Corporation. 2002. Guide to using @ Risk version 4.5: advanced risk analysis for spreadsheets. Pallisade Corporation, Newfield, New York, U.S.

Portney P.R., and J.P. Weyant. 1999. Discounting and intergenerational equity. Resources for the Future. 186 pp.

Prasad, A.M., L.R. Iverson, M.P. Peters, J.M. Bossenbroek, S.N. Matthews, T. Sydnor, and M.W. Schwartz. 2010. Modeling the invasive emerald ash borer risk of spread using a spatially explicit cellular model. Landscape Ecology, 25:353-369.

Rebek, E.J., D.A. Herms, and D.R. Smitley. 2008. Interspecific variation in resistance to emerald ash borer (Coleoptera: Buprestidae) among North American and Asian ash (Fraxinus spp.). Environmental Entomology 37:242-246.

Sadof, C.S., L. Purcell, F.J. Bishop, C. Quesada, and Z. Zhang. 2011. Evaluating restoration capacity and costs of managing the emerald ash borer with a web-based cost calculator in urban forests. Arboriculture \& Urban Forestry 37:74-83.

Schwan, T.D., and K.A. Elliott. 2010. Effects of diameter-limit by-laws on forestry practices, economics, and regional wood supply for private woodlands in southwestern Ontario. The Forestry Chronicle 86:623-635

Smitley, D.R., T. Davis, and E.J. Rebek. 2008. Progression of ash canopy thinning and dieback outward from the initial infestation of emerald ash borer (Coleoptera: Buprestidae) in southeastern Michigan. Journal of Economic Entomology 101:1643-1650.

Smith, E. L., A.J. Storer, and B.K. Roosien. 2009. Emerald ash borer infestation rates in Michigan, Ohio, and Indiana. p. 96. In: K.A. McManus and K.W. Gottschalk. Proceedings. 20th U. S. Department of Agriculture interagency research forum on invasive species 2009. Gen. Tech. Rep. NRS-P-51. Newtown, PA, U.S. Department of Agriculture, Forest Service, Northern Research Station.

Statistics Canada. 2007. Community Profiles. 2006 Census. Statistics Canada Catalogue no. 92-591-XWE. <www12.statcan.ca/censusrecensement/2006/dp-pd/prof/92-591/index.cfm?Lang=E $>$

Sydnor, T.D., M. Bumgardner, and A. Todd. 2007. The potential economic impacts of emerald ash borer (Agrilus planipennis) on Ohio, U.S., communities. Arboriculture \& Urban Forestry 33:48-54.

Sydnor, T.D., M. Bumgardner, and S. Subburayalu. 2011. Community ash densities and economic impact potential of emerald ash borer (Agrilus planipennis) in four midwestern states. Agriculture \& Urban Forestry 37:84-89.

Taylor, R.A.J., L.S. Bauer, T.M. Poland, and K.N. Windell. 2010. Flight performance of Agrilus planipennis (Coleoptera: Buprestidae) on a flight mill and in free flight. Journal of Insect Behavior 23:128-148.

USDA-APHIS. 2011. Emerald ash borer quarantine map. Accessed 06/14/2011. <www.aphis.usda.gov/plant_health/plant_pest_info/emerald_ash_b/downloads/multistateeab.pdf>

Weitzman, M. 1994. On the "environmental" discount rate. Journal of Environmental Economics and Management 26:200-209. 
Woodall, C.W., C.M. Oswalt, J.A. Westfall, C.H. Perry, M.D. Nelson, and A.O. Finley. 2009. An indicator of tree migration in forests of the eastern United States. Forest Ecology and Management 257:1434-1444.

Yemshanov, D., F.H. Koch, D.W. McKenney, M.C. Downing, and F.F. Sapio. 2009a. Mapping invasive species risks with stochastic models: A cross-border United States-Canada application for Sirex noctilio Fabricius. Risk Analysis 29:868-884.

Yemshanov, D., D.W. McKenney, P. de Groot, D. Haugen, D. Sidders, and B. Joss. 2009b. A bioeconomic approach to assess the impact of an alien invasive insect on timber supply and harvesting: A case study with Sirex noctilio in eastern Canada. Canadian Journal of Forest Research 39:154-168.

Daniel W. McKenney (corresponding author)

Natural Resources Canada, Canadian Forest Service

Great Lakes Forestry Centre

1219 Queen Street East

Sault Ste. Marie, ON, P6A 2E5, Canada

Dan.McKenney@NRCan-RNCan.gc.ca

John H. Pedlar

Natural Resources Canada, Canadian Forest Service

Great Lakes Forestry Centre

1219 Queen Street East

Sault Ste. Marie, ON, P6A 2E5, Canada

\section{Denys Yemshanov}

Natural Resources Canada, Canadian Forest Service

Great Lakes Forestry Centre

1219 Queen Street East

Sault Ste. Marie, ON, P6A 2E5, Canada

D. Barry Lyons

Natural Resources Canada, Canadian Forest Service

Great Lakes Forestry Centre

1219 Queen Street East

Sault Ste. Marie, ON, P6A 2E5, Canada

Kathy L. Campbell

Natural Resources Canada, Canadian Forest Service

Great Lakes Forestry Centre

1219 Queen Street East

Sault Ste. Marie, ON, P6A 2E5, Canada

Kevin Lawrence

Natural Resources Canada, Canadian Forest Service

Great Lakes Forestry Centre

1219 Queen Street East

Sault Ste. Marie, ON, P6A 2E5, Canada
Résumé. L'agrile du frêne est un insecte perceur invasif qui cause la mortalité à grande échelle des frênes (Fraxinus spp.) en Amérique du Nord. La présente étude présente une estimation des coûts économiques associés à la mortalité par l'agrile des frênes le long des rues et dans les cours arrières privées en milieu urbain au Canada sur une période de 30 ans. L'approche a fait appel un simple modèle de dispersion pour estimer le moment d'arrivée de l'agrile du frêne au sein de chaque ville en se basant sur trois vitesse maximales de propagation: lente $(\sim 10 \mathrm{~km} / \mathrm{an})$, moyenne $(\sim 30$ $\mathrm{km} / \mathrm{an})$ et rapide $(\sim 50 \mathrm{~km} / \mathrm{an})$. Les coûts sont estimés en fonction de quatre taux d'escompte $(0 \%, 2 \%, 4 \%$ et $10 \%)$ et trois niveaux de traitement $(0 \%$, $10 \%$ et $50 \%$ des arbres traités avec un insecticide). La densité en frêne le long des rues urbaines a été estimée à partir de sources variées, incluant une méthode d'évaluation récemment développée qui permet une évaluation rapide de la composition en arbres des rues. En se basant sur une vitesse de propagation de $30 \mathrm{~km} / \mathrm{an}$, un taux d'escompte de $4 \%$ et un taux de traitement de $10 \%$, les coûts sont estimés à environ 524 millions de dollars CAN (en dollars de 2010); cette valeur s'accroît de manière brute d'environ 890 millions de dollars si on y ajoute les coûts associés aux arbres dans les cours arrières privées. Ces estimations sont conservatrices parce qu'elles mettent en évidence seulement les dommages associés aux arbres de rues (et dans les cours arrières privées); quoiqu'il en soit, leur magnitude constitue une justification majeure pour investir dans les moyens qui permettront de ralentir la progression de l'agrile du frêne au Canada.

Zusammenfassung. Der Asiatische Eschenprachtkäfer (EAB) ist ein invasives, Phloem-schädigendes Insekt, welches zu flächendeckendem Absterben von Eschen in Nordamerika führt. Die gegenwärtige Studie bewertet die ökonomischen Kosten, die mit dem massenhaften Absterben von Eschen als Strassenbäume durch den EAB in Kanadas besiedelten Räumen über einen Zeitraum von 30 Jahren. Der Ansatz verwendet ein einfaches Streumodel zur Abschätzung des Eintreffens des Käfers in der jeweiligen Kommune, basierend auf drei maximalen Streuraten: langsam $(\sim 10 \mathrm{~km} / \mathrm{Jahr})$, mittel $(\sim 30 \mathrm{~km} / \mathrm{Jahr})$, und schnell $(\sim 50 \mathrm{~km} / \mathrm{Jahr})$. Die Kosten wurden für vier Abschlagsraten $(0 \%, 2 \%, 4 \%$, und $10 \%)$ und drei Behandlungsraten $(0 \%, 10 \%$, und $50 \%$ der Bäume, die mit einem Insektizid behandelt wurden). Die Eschendichte entlang der Strassen wurde anhand von verschiedenen Quellen geschätzt, einschließlich einer kürzlich entwickelten Erhebung, die eine schnelle Erfassung der Baumartenzusammensetzung erlaubt. Basierend auf der $30 \mathrm{~km} / \mathrm{Jahr}$-Ausbreitungsrate, einer $4 \%$ Abschlagsrate und einer $10 \%$ Behandlungsrate wird der gegenwärtige Wert der Kosten mit schätzungsweise CAD\$ 524 Millionen(WechselkursStand 2010) angenommen. Dieser Wert steigt grob geschätzt auf $\$ 890$ Millionen, wenn die Kosten der Bäume in den Hinterhöfen hinzuaddiert werden. Die Schätzungen sind konservativ, weil sie nur auf den Schaden an Strassen- (und Hinterhof-)bäumen fokussieren, nichtsdestotrotz gibt ihre Höhe doch eine ernstzunehmenden Faktor bei der Berechnung von Investitionen zur Eindämmung des Prachtkäfers in Kanada.

Resumen. El barrenador esmeralda del fresno (EAB) es un insecto invasivo del floema que causa mortalidad extensiva del fresno (Fraxinus $\mathrm{sp}$ ) en Norte América. Este estudio estimó los costos económicos asociados con EAB-mortalidad relacionada de árboles de calles y patios en áreas urbanas de Canadá en un periodo de 30 años. Esta aproximación empleó un modelo simple de propagación para los tiempos de arribo de EAB a cada comunidad con base en tres tasas máximas: lenta ( $10 \mathrm{~km} / \mathrm{año})$, media ( $30 \mathrm{~km} / \mathrm{año})$, y rápida $(\sim 50 \mathrm{~km} / \mathrm{año})$. Los costos son estimados para cuatro tasas de descuento $(0 \%, 2 \%, 4 \%$, y $10 \%)$ y tres tasas de tratamiento $(0 \%, 10 \%, y 50 \%)$ de árboles tratados con un insecticida. Se estimó la densidad del fresno a lo largo de las vías urbanas de una variedad de fuentes, incluyendo una encuesta reciente que permite una evaluación rápida de la composición de árboles. Con base en una tasa de propagación de $30 \mathrm{~km} /$ año, una tasa de descuento del $4 \%$, y una tasa de tratamiento del $10 \%$, el valor presente de los costos es estimado aproximadamente en CAD \$524 millones (valores del 2010); este valor incrementa a $\$ 890$ millones cuando se incluyen los costos asociados con árboles de los patios. Estas estimaciones son conservadoras debido a que se enfocan solamente al daño a árboles de las calles (y patios); no obstante, su magnitud sugiere justificación considerable de inversiones para reducir la propagación de EAB en Canadá. 